\title{
A novel GH secretagogue, A233, exhibits enhanced growth activity and innate immune system stimulation in teleosts fish
}

\author{
Rebeca Martinez, Kenia Ubieta ${ }^{1}$, Fidel Herrera, Alina Forellat ${ }^{1}$, Reynold Morales, Ania de la Nuez ${ }^{2}$, \\ Rolando Rodriguez ${ }^{2, *}$, Osvaldo Reyes ${ }^{2}$, Ayme Oliva and Mario P Estrada \\ Biotechnology Animal Division, Aquatic Biotechnology Department, CIGB, PO Box 6162, Havana 10600, Cuba \\ ${ }^{1}$ Biochemistry Department, Faculty of Biology, Havana University, Havana, Cuba \\ ${ }^{2}$ Physico-Chemistry Division, Center for Genetic Engineering and Biotechnology, PO Box 6162, Havana 10600, Cuba \\ (Correspondence should be addressed to M P Estrada; Email: mario.pablo@cigb.edu.cu) \\ *(R Rodriguez is currently at Computational Medicine, National Institute of Nephrology, Havana, Cuba)
}

\begin{abstract}
In teleosts fish, secretion of $\mathrm{GH}$ is regulated by several hypothalamic factors that are influenced by the physiological state of the animal. There is an interaction between immune and endocrine systems through hormones and cytokines. $\mathrm{GH}$ in fish is involved in many physiological processes that are not overtly growth related, such as saltwater osmoregulation, antifreeze synthesis, and the regulation of sexual maturation and immune functions. This study was conducted to characterize a decapeptide compound A233 (GKFDLSPEHQ) designed by molecular modeling to evaluate its function as a $\mathrm{GH}$ secretagogue (GHS). In pituitary cell culture, the peptide A233 induces GH secretion and it is also able to increase superoxide production in tilapia head-kidney leukocyte cultures. This effect is blocked by
\end{abstract}

preincubation with the GHS receptor antagonist [D-Lys $\left.{ }^{3}\right]-$ GHRP6. Immunoneutralization of $\mathrm{GH}$ by addition of anti-tilapia $\mathrm{GH}$ monoclonal antibody blocked the stimulatory effect of A233 on superoxide production. These experiments propose a GH-mediated mechanism for the action of A233. The in vivo biological action of the decapeptide was also demonstrated for growth stimulation in goldfish and tilapia larvae $(P<0 \cdot 001)$. Superoxide dismutase levels, antiprotease activity, and lectin titer were enhanced in tilapia larvae treated with this novel molecule. The decapeptide A233 designed by molecular modeling is able to function as a GHS in teleosts and enhance parameters of the innate immune system in the fish larvae.

Journal of Endocrinology (2012) 214, 409-419

\section{Introduction}

Growth hormone $(\mathrm{GH})$ has pleiotropic functions in all vertebrates. In addition to its essential role in the regulation of body growth and development, it can also influence reproduction, immunity, osmoregulation, and behavior (Rise et al. 2006, Acosta et al. 2008, Devlin et al. 2009). In teleosts, secretion of GH is regulated by several hypothalamic factors that are influenced by the physiological state of the animal. In fish, GH-releasing hormone, gonadotrophin-releasing hormone $(\mathrm{GNRH})$, neuropeptide $\mathrm{Y}$, and thyrotrophin-releasing hormone (TRH) stimulate the release of $\mathrm{GH}$, effects that have been shown to be influenced by gonadal sex steroids and by the nutritional state of the animal (Sherwood et al. 2000). Intrapituitary regulators, including $\mathrm{GH}$, gonadotropin, and inhibin/activin, provide autocrine/paracrine control over GH synthesis and secretion (Chang \& Wong 2009). Besides the pituitary gland, the GH gene is also expressed in other tissues of fish, especially in lymphoid organs and cells (Yada 2007).

The synthetic GH secretagogues (GHSs) consist of a family of ligands, first described by Momany et al. (1981). They were initially termed GH-releasing peptides (GHRPs). Multiple efforts have been directed toward finding the active molecules with an increased oral bioavailability and longer clearance times, yielding the discovery of new GHSs (Moulin et al. 2007).

GHS bind to a receptor inducing calcium mobilization, as identified by Howard et al. (1996) in pigs and humans. Currently, GHS receptor (GHSR) has been identified in teleosts and birds (Palyha et al. 2000, Kaiya et al. 2009a,b,c, 2010). More than one receptor has been proposed for zebrafish, catfish, and goldfish (Kaiya et al. 2008, 2010, Small et al. 2009).

The endogenous ligand to this receptor was identified by Kojima et al. (1999) as ghrelin (GRLN), which is a 28 -amino acid peptide synthesized mainly in the oxyntic mucosal cells of the stomach and which has diverse actions such as potent GH-releasing and orexigenic activities, insulonistasis, cardiovascular effects, stimulation of gastric motility and acid secretion, adipogenesis, and cell proliferation (Muccioli et al. 2007, Veldhuis \& Bowers 2010).

Neuroendocrine and immune systems interact in a directional fashion. In this way, the status of pathogen recognition is communicated to the brain and the immune 
response is influenced by physiological changes. This explicit communication consequently needs a common language of signaling molecules and receptors. Growing evidence suggests that hormones not only act on neuroendocrine cells but also on immune cells and that cytokines act on both immune and neuroendocrine cells via shared receptors in both systems and modulate their functions. GHSR is expressed predominantly in the brain and pituitary, but it is also expressed in many peripheral organs including immune system cells (Hattori et al. 2001). GRLN modulates the immune system (Dixit et al. 2004) and it has been shown to stimulate phagocytosis in fish leukocytes, and this effect is mediated in part by GH secreted by leukocytes (Yada et al. 2006).

The molecule A233 was described by the exhaustive molecular modeling of the human GRLN receptor using combined techniques of homology modeling, molecular dynamics, and exhaustive conformational search techniques, after which a virtual library was built with several thousands of structures having such characteristics, to perform a conformational analysis, and a massive docking experiment was performed against the receptor model (Rodriguez et al. 2007). The aim of this study was to assess the biological activity of synthetic peptide A233 as a stimulator of growth and the innate immune system of teleosts fish, through studies performed in vitro and in vivo.

In this study, we have characterized a chemical decapeptide compound, A233, designed by molecular modeling, which is able to perform the function of a GH peptide secretagogue. Innate immune system stimulation is also obtained in vitro in tilapia head-kidney leukocyte (HKL) cultures using this molecule through a GHSR-dependent pathway. By means of immune neutralization experiments, we have proved the mechanism of action of A233 to be GH-mediated. We also show the biological action in vivo of the molecule, for growth stimulation in goldfish and tilapia larvae and enhancing the level of some innate immune parameters and the superoxide dismutase $(\mathrm{SOD})$ in tilapia larvae treated with this novel secretagogue.

\section{Materials and Methods}

\section{Fish}

Goldfish (Carassius auratus) were provided by Nacari Company, Havana, Cuba. Tilapia (Oreochromis sp.) juvenile and larvae were obtained from the Center for Aquaculture of Mampostón (CPAM). Fish were kept alive in aerated freshwater under a $12 \mathrm{~h}$ light: $12 \mathrm{~h}$ darkness photoperiod. They were fed commercial dry diet for fish (CENPALAB, Habana, Cuba). Water temperature was maintained at 26 and $28^{\circ} \mathrm{C}$. All animal experiments were previously approved by the Ethics Committee of the Center for Genetic Engineering and Biotechnology, Havana, Cuba.

\section{GH secretagogues}

The decapeptide A233 (GKFDLSPEHQ) with a lactam bond between side chains of Lys and Asp (underlined amino acids) was manually synthesized on a solid-phase support. Crude peptide was purified by reverse-phase, high-performance, liquid chromatography up to $95 \%$ on a C-18 preparative column with an acetonitrile/water linear gradient. Trifluoracetic acid was used in both solvents for counter-ion pair formation. The correct sequence of the purified peptide was confirmed by electrospray mass spectrometry (Micromass, Manchester, UK). The positive control used was GHRP6 (Lipotec, Barcelona, Spain) and the antagonist [D-Lys $\left.{ }^{3}\right]-$ GHRP6 (Sigma) lyophilized peptides were reconstituted in PBS for use in vitro and in vivo.

\section{Primary culture of pituitary cells}

The in vitro effects of A233 GHS were examined using cells dispersed from whole pituitary. Mature tilapias of both sexes weighing $300-500 \mathrm{~g}$ were used after anesthesia in tricaine methanesulfonate (MS-222, Sigma). Pituitaries were collected aseptically in isotonic medium (Krebs bicarbonateRinger solution, $330 \mathrm{~m}$ Osmolal, $\mathrm{pH}$ 7.4) supplemented with penicillin $(100 \mathrm{IU} / \mathrm{ml})$, streptomycin $(0 \cdot 1 \mathrm{mg} / \mathrm{ml})$, and nystatin $(250 \mathrm{IU} / \mathrm{ml}$, all from Sigma). The pituitaries were diced with a sterile razor blade and treated with collagenase for $1 \mathrm{~h}$ at room temperature in $2.5 \mathrm{ml}$ trypsin-EDTA solution $(0 \cdot 25 \%$ trypsin $+0 \cdot 02 \%$ EDTA in PBS, $\mathrm{pH} 7 \cdot 4)$. Tissues were aspirated repeatedly through a pipette during enzymatic treatment to promote dissociation of cells. The process was terminated by the addition of $0.5 \mathrm{ml}(20 \%)$ fetal bovine serum (Sigma). Cells were counted on a hemocytometer under a light microscope and viability determined by trypan blue exclusion. Viability of the cells was always $>95 \%$. Cells were then plated at a density of $4 \cdot 0 \times 10^{5}$ cells/well into a $24-$ well plate (Falcon, Primaria 24, Becton Dickinson, Franklin Lakes, NJ, USA) at a volume of $300 \mu \mathrm{l} /$ well of isotonic medium supplemented with $10 \%$ fetal bovine serum. The cells were preincubated for 4 days at $26-28{ }^{\circ} \mathrm{C}$ under a humidified atmosphere of $95 \% \mathrm{O}_{2}$ and $5 \% \mathrm{CO}_{2}$, with one change of culture medium at $48 \mathrm{~h}$ post-plating. Before each experiment, cells were washed once with serum-free medium. A final $300 \mu \mathrm{l}$ serum-free medium was added containing A233, GHRP6 (Lipotec), or control medium without hormones. The medium was replaced at $4 \mathrm{~h}$. Incubations were terminated at $8 \mathrm{~h}$, and hormone release was quantified for the $0-4$ and $4-8 \mathrm{~h}$ intervals. GH release was expressed as secretion per unit volume of medium $(\mathrm{ng} / \mathrm{ml})$.

\section{GH assays}

The GH secreted in vitro was measured using a noncompetitive ELISA as described by Lugo et al. (2008). The 96-well MaxiSorp plates (Nalge Nunc International, Roskilde, Denmark) were coated $\left(3 \mathrm{~h}\right.$ at $\left.37^{\circ} \mathrm{C}\right)$ with anti-tilapia $\mathrm{GH}$ monoclonal antibody 1 (tiGH1 mAb; CIGB, Santi Spiritus,

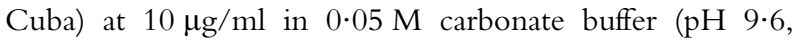
$100 \mu \mathrm{l} /$ well). The plates were washed two times with PBS-T $\left(137 \mathrm{mM} \mathrm{NaCl}, 2 \cdot 7 \mathrm{mM} \mathrm{KCl}, 4 \cdot 3 \mathrm{mM} \mathrm{Na} 2 \mathrm{HPO}_{4} \cdot 7 \mathrm{H}_{2} \mathrm{O}\right.$, 
and $0.05 \%$ Tween $20, \mathrm{pH} 7 \cdot 3$ ) and blocked with $3 \%$ skim milk (Oxoid, Cambridge, UK) in PBS $1 \times(200 \mu \mathrm{l} /$ well) for $1 \mathrm{~h}$ at $37^{\circ} \mathrm{C}$. A standard tiGH curve in the range of $35-0.136 \mathrm{ng} / \mathrm{ml}$ was obtained by twofold dilutions in $0.5 \%$ skim milk in PBS $1 \times$, dispensed by duplicate in the same plate. Test samples were diluted at a ratio of $1: 2$ as described earlier and were incubated on the plates overnight at $4{ }^{\circ} \mathrm{C}$. After washing the plates four times with PBS-T, $100 \mathrm{ml} \mathrm{HRP}-\mathrm{tiGH} 2 \mathrm{mAb}$ conjugate (CIGB), diluted at a ratio of 1:15 000 in PBS $1 \times$ containing $0.5 \%$ skim milk, were added to each well. The plates were incubated for $1 \mathrm{~h}$ at $37^{\circ} \mathrm{C}$ and then washed eight times with PBS-T. Then, the substrate buffer $\left(0 \cdot 2 \mathrm{M} \mathrm{Na}_{2} \mathrm{HPO}_{4}, 0 \cdot 1 \mathrm{M}\right.$ citric acid ( $\mathrm{pH} 5 \cdot 0$ ) containing $0.5 \mathrm{mg} / \mathrm{ml}$ ortho-phenylenediamine and $\left.5 \mu \mathrm{l} 30 \% \mathrm{H}_{2} \mathrm{O}_{2}\right)$ was added $(100 \mu \mathrm{l} /$ well). The reaction was stopped $15 \mathrm{~min}$ later by adding $50 \mu \mathrm{l}$ of $2.5 \mathrm{M}$ sulfuric acid per well. The absorbance was measured at $492 \mathrm{~nm}$ using the Titertek Multiskan Plus spectrophotometer. The accepted upper limit of the assay background was 0.094. The lower detection limit of the assay was $0 \cdot 1 \mathrm{ng} / \mathrm{ml}$. The degree of variation and intra- and interassay coefficients of variation are 3.90 and $13.45 \%$ respectively.

\section{Isolation of HKLS}

HKLs were isolated as described by Yada et al. (2006) with slight modifications. Fish were killed by decapitation and the head-kidney was placed in RPMI-1640 medium (Sigma). The cells were layered on a 34/51\% Percoll (Sigma-Aldrich) gradient and centrifuged at $10000 \mathrm{~g}$ for $45 \mathrm{~min}$. The leukocyte band was harvested, washed with Hanks' solution ( $\mathrm{pH} 7 \cdot 4$; Sigma), and suspended in RPMI-1640 medium (Sigma). The leukocytes were counted using a Neubauer Haemocytometer from an aliquot containing $900 \mu \mathrm{l}$ of $0 \cdot 1 \%$ trypan blue and $100 \mu \mathrm{l}$ of cell suspension.

\section{Superoxide production in HKLs}

To analyze the effect of GHSs on the immune system, the superoxide anion was measured in HKLs as the reduction of NBT (Sigma) as described by Sakai et al. (1996) and Yada et al. (2006). To examine whether A233 acts through the GHSR, leukocytes were exposed to the GHSR antagonist [D-Lys ${ }^{3}$, GHRP6 $(10 \mu \mathrm{M})$. On the day of treatment, cells were preincubated for $1 \mathrm{~h}$ with either control medium or medium containing [D-Lys $\left.{ }^{3}\right]-G H R P 6$. Preincubation medium was then aspirated and replaced with fresh medium containing either A233 or GHRP6 $10 \mathrm{nM}$.

\section{GH immunoneutralization assay}

To assay immunoneutralization against $\mathrm{GH}$, the cells were incubated with GHRP6 or A233 $(10 \mathrm{nM})$ in the presence of anti-tiGH mAb (CIGB) at a concentration of $0 \cdot 1,1$, and $10 \mu \mathrm{g} / \mathrm{ml}$ for $4 \mathrm{~h}$ at $28{ }^{\circ} \mathrm{C}$ in $5 \% \mathrm{CO}_{2}$. Superoxide production was measured as described earlier.

\section{Growth performance experiment}

The growth promoting activity of A233 was evaluated in tilapia larvae (Oreochromis sp.) of $0.007 \pm 0.001 \mathrm{~g}$ and goldfish (C. auratus) larvae of $0.003 \pm 0.0008 \mathrm{~g}$ mean weight and $0.610 \pm 0.09 \mathrm{~cm}$ length $(n=200)$. The effect was compared with GHRP6 as positive control. The fish were acclimated at $28^{\circ} \mathrm{C}$ in 1201 tanks with running fresh water for 1 week before the experiment. They were fed with a basal diet to satiation twice a day. Before treatment, the tanks were cleaned. The fish were immersed into each treatment for $60 \mathrm{~min}$ without water recirculation. The immersion procedure was performed three times a week, for a period of 1 month. Three experimental groups were handled with the following treatments: groups 1 and 2 received the peptides A233 and GHRP6 (positive control) at a dose of $0 \cdot 1 \mathrm{mg} / \mathrm{l}$, respectively, and a nontreated group in the third one. Growth-promoting effects were evaluated by measuring the body weight and increase in length.

\section{Homogenates of larvae}

Larvae were washed three times with sterile PBS $1 \times$ : $137 \mathrm{mM} \mathrm{NaCl}, 2 \cdot 7 \mathrm{mM} \mathrm{KCl}$, and $4.3 \mathrm{mM} \mathrm{Na}_{2} \mathrm{HPO}_{4} \cdot 7 \mathrm{H}_{2} \mathrm{O}$ at $\mathrm{pH} 7 \cdot 3$. The larvae were homogenized using $10 \mathrm{ml}$ PBS $1 \times / \mathrm{g}$ of tissue and centrifuged at $5000 \mathrm{~g}$ for $15 \mathrm{~min}$ at $4{ }^{\circ} \mathrm{C}$. The supernatants were collected and stored at $-70^{\circ} \mathrm{C}$. The protein concentration of larval homogenates was measured with BCA Protein Assay Kit (Thermo Scientific, Rockford, IL, USA) according to manufacturer's instructions.

\section{Hemagglutination assay for lectins}

Serial twofold dilutions of $100 \mu \mathrm{l}$ larval extracts were performed using PBS $(\mathrm{pH} 7 \cdot 2)$ in U-bottom shaped (96 wells, Greiner Bio-One GmbH, Frickenhausen, Germany, Microlon) microtiter wells to which an equal volume of freshly prepared $2 \%$ erythrocyte suspension (rabbit in PBS) was added (Jung et al. 2003). Wells were incubated for $1 \mathrm{~h}$ at room temperature and the titer was read visually and was equal to the dilution in the last well to show agglutination (as manifested by an evenly distributed layer of cells over the whole well bottom). The hemagglutinin activity of samples was examined and for each a titer value was obtained. The activity was expressed as titer, i.e. the reciprocal of the highest dilution showing complete agglutination.

\section{Antiprotease activity}

Antiprotease activity was performed as described by Magnadottir et al. (1999). Briefly, $20 \mu l$ larval homogenates were incubated with the same volume of standard trypsin solution (Sigma, $5 \mathrm{mg} / \mathrm{ml}$ ) for $10 \mathrm{~min}$ at $22^{\circ} \mathrm{C}$. To this, $200 \mathrm{ml}$ of $0 \cdot 1 \mathrm{M}$ phosphate buffer $(\mathrm{pH} 7 \cdot 0)$ and $250 \mathrm{ml}$ $2 \%$ azocasein (Sigma) were added and incubated for $1 \mathrm{~h}$ at $22{ }^{\circ} \mathrm{C}$. Then, $500 \mathrm{ml}$ of $10 \%$ trichloroacetic acid was added and 

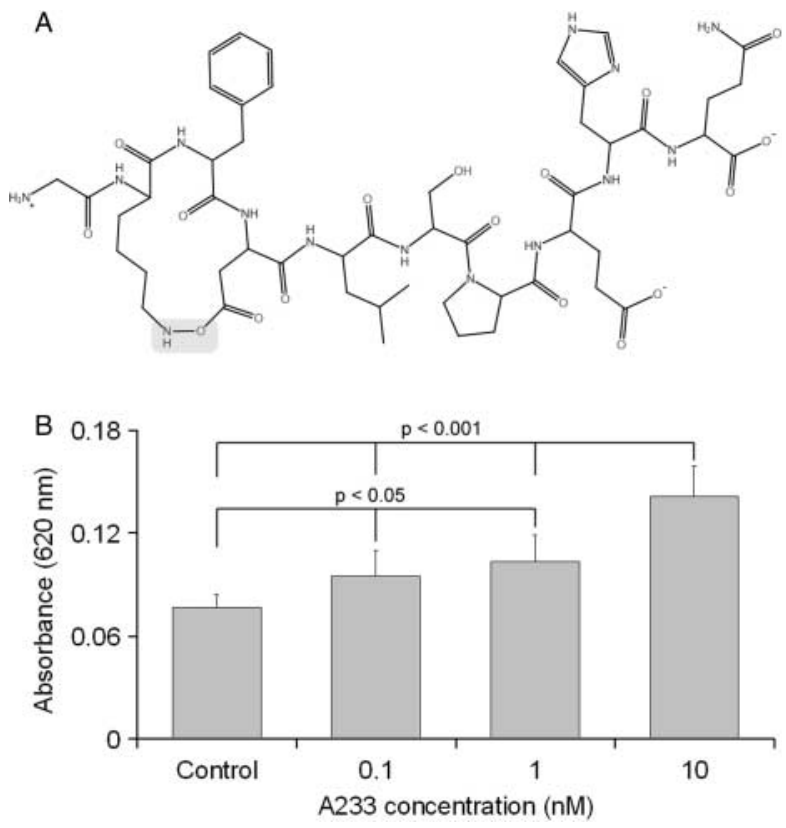

Figure 1 (A) 2D representation of the peptide amide A233 (GKFDLSPEHQ). The lactam bond between Lys and Asp was formed during the synthesis procedure on solid-phase support and is essential for the biological activity of the molecule. The lactam bond is indicated by shadow rectangle. (B) Dose-related effects of A233 on superoxide anion production by tilapia (Oreochromis sp.) HKLs. Cells were incubated with A233 for $4 \mathrm{~h}$ at $28{ }^{\circ} \mathrm{C}$ in $5 \% \mathrm{CO}_{2}$. Cells with Hanks' solution $(\mathrm{pH} 7 \cdot 4)$ were the control. Data are expressed as the absorbance at $620 \mathrm{~nm}$ and bars represent S.D. of the mean (S.E.M., $n=5$ ). Statistical differences between groups for Newman-Keuls's test.

incubated for $30 \mathrm{~min}$ at $22{ }^{\circ} \mathrm{C}$. The mixture was centrifuged at $6000 \mathrm{~g}$ for $5 \mathrm{~min}$. The supernatant $(100 \mu \mathrm{l})$ was transferred to a 96-well microtray containing $100 \mu \mathrm{l} /$ well of $1 \mathrm{M} \mathrm{NaOH}$. The OD was read at $450 \mathrm{~nm}$. For a $100 \%$ control, buffer replaced the serum and for a negative control, buffer replaced both serum and trypsin. The percentage of inhibition of trypsin activity by each sample was calculated by comparing it to the $100 \%$ control sample. All the samples collected were analyzed in triplicates.

\section{Determination of SOD in tilapia larval homogenates}

SOD (superoxide dismutase) activity was determined based on the ability of the enzyme to inhibit the auto-oxidation of pyrogallol as described by Ecobichon (1984).

\section{Statistical analysis}

Results were evaluated using GraphPad Prism version 4.0 for Windows, GraphPad Software, San Diego, CA, USA. All results are expressed as the mean \pm s.D. Statistical analysis was performed using one-way ANOVA by Newman-Keuls's or Dunnett's method for data with normal distribution and equal variances: GH assays, superoxide production, GH immunoneutralization assay, growth performance experiment of tilapia (Oreochromis sp.) larvae, and hemagglutination assay for lectins, antiprotease, and SOD activity. Data with unequal variances were analyzed by the Kruskal-Wallis test followed by Dunn's multiple comparisons post-test: growth performance experiment of goldfish (C. auratus) larvae. Treatments were considered to be significantly different if $P<0 \cdot 05$.

\section{Results}

The molecule A233 (Fig. 1A) was selected from the virtual libraries described by Rodriguez et al. (2007), and, in order to determine in vitro and in vivo whether this novel mimetic molecule of natural or synthetic GHSs maintains some of its biological functions, the following assays were conducted on the growth and immune system.

\section{GH in vitro assays using pituitary cell culture}

To evaluate the effect of A233 peptide on GH secretion, we performed an in vitro culture of cells in the pituitary gland of tilapia (Oreochromis sp.). GH secretion did not increase in culture of cells after $4 \mathrm{~h}$ of treatment with A233. At $8 \mathrm{~h}$, the supernatant of cells that received $1 \mathrm{nM}$ A233 peptide did not show a significant increase in GH concentration present; however, the A233 peptide at a concentration of $10 \mathrm{nM}$ stimulated $\mathrm{GH}$ secretion by cells in the anterior pituitary gland (Table 1). The stimulatory effect of GRLN and GHSs on the release of GH in vitro by the pituitary gland has been reported in mammals, birds, and different species of fish (Kaiya et al. 2003a,b, 2008, Unniappan \& Peter 2004, Boaz 2005, Fox et al. 2007, Picha et al. 2009).

Determination and characterization of superoxide anion induction in HKLs

Production of superoxide anion by cultured tilapia (Oreochromis sp.) in HKLs was measured by the addition of A233. This peptide induced significant increases in superoxide production. The peptide A233 at concentrations from $0 \cdot 1$ to

Table 1 Effects of the A233 on GH secretion by cultured tilapia pituitary cells. Experiments were tested in triplicate with pituitaries from six animals. Data represent arithmetic mean of the tilapia $\mathrm{GH} \pm$ s.D.

\section{GH concentration $(\mathrm{ng} / \mathrm{ml})$}

\begin{tabular}{|c|c|}
\hline $4 \mathrm{~h}$ & $8 \mathrm{~h}$ \\
\hline $0 \cdot 169 \pm 0 \cdot 05$ & $0 \cdot 13 \pm 0 \cdot 03$ \\
\hline $0 \cdot 16 \pm 0 \cdot 05$ & $0 \cdot 15 \pm 0 \cdot 05$ \\
\hline $0 \cdot 18 \pm 0 \cdot 07$ & $0 \cdot 30 \pm 0 \cdot 08^{a}$ \\
\hline $0 \cdot 05 \pm 0 \cdot 04$ & $0 \cdot 16 \pm 0.09$ \\
\hline $0 \cdot 04 \pm 0 \cdot 02$ & $0 \cdot 42 \pm 0 \cdot 06^{\mathrm{a}}$ \\
\hline
\end{tabular}

${ }^{\text {aS }}$ ignificantly different from control in the same column $(P<0 \cdot 05)$. 


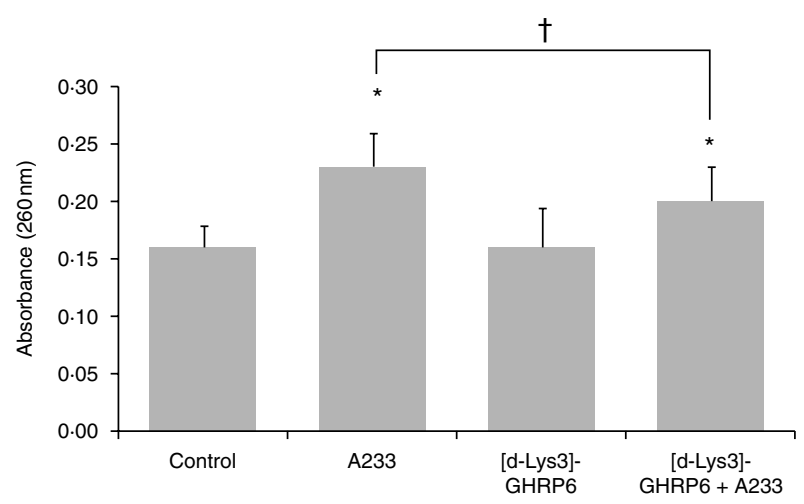

Figure 2 Effects of the GHSR-specific antagonist, [D-Lys ${ }^{3}$ ]-GHRP6, on superoxide production in phagocytic HKLs. Cells were preincubated with [D-Lys ${ }^{3}$ ]-GHRP6 $(10 \mu \mathrm{M})$ for $1 \mathrm{~h}$ and incubated with A233 $(10 \mathrm{nM})$ for $4 \mathrm{~h}$. Data are expressed as the absorbance at $620 \mathrm{~nm}$ and bars represent S.D. of the mean (S.E.M., $n=5$ ).

*Significantly different from respective control; ${ }^{\dagger}$ significant differences between columns for Student's $t$-test.

$10 \mathrm{nM}$ increased superoxide production in the phagocytic HKL in a dose-dependent manner (Fig. 1B). Preincubation of HKLs with [D-Lys ${ }^{3}$ ]-GHRP6 $(10 \mu \mathrm{M})$ for $1 \mathrm{~h}$ significantly suppressed the stimulatory effects of A233 (10 nM) on superoxide anion production after $4 \mathrm{~h}$ of incubation (Fig. 2).

Owing to the importance of phagocytic cells in the immune response in fish, we evaluated the effect of peptide on A233 in vitro superoxide anion production in phagocitic leukocytes isolated from tilapia (Oreochromis sp.). The increase of superoxide anion production was statistically higher in cells stimulated with the highest dose of peptide tested $(10 \mathrm{nM})$. Similarly, the stimulatory effect of the peptide, the increase in reactive oxygen species (ROS), was also evident in isolated tilapia peripheral blood leukocytes (data not shown). These results are consistent with those observed in leukocytes from the anterior kidney of rainbow trout (Oncorhynchus mykiss) stimulated in vitro with different doses of des-GRLN or GRLN VRQ - the same kind (Yada et al. 2006). Additionally, this effect is similar to that reported by Acosta et al. (2010), who stimulated phagocytic peripheral blood cells of tilapia (Oreochromis sp.) with recombinant tiGH (Oreochromis hornorum). Addition of anti-tiGH mAb to the cultured HKLs mixed with A233 resulted in significant inhibition of superoxide production, thereby showing a GH-mediated mechanism (Fig. 3).

In vivo biological activity assays

Experiments were performed to evaluate the biological effect of the peptide on the growth rate of goldfish and tilapia larvae. The effect of these peptides on fish growth was determined by measuring the increase in body weight and length. The goldfish larvae treated with A233 showed a highly significant increase in body weight and length compared with the controls just 7 days after treatment and significant differences also compared with the positive control group treated with
GHRP6 (positive control). However, there were no statistically significant differences in larval length between the A233 and GHRP6 treatment groups (Fig. 4).

In the assay with tilapia larvae, the wet body weight and size were recorded at 30 days from the beginning of the experiment. Statistically significant differences in weight were found in tilapia larvae treated with the A233 peptide compared with the nontreated group, as well as larvae treated with GHRP6. No statistically significant difference in length was observed between the GHRP6 and A233 groups during the experiment (Fig. 4).

No statistical differences in protein concentration, antiprotease activity, and lectin titer were found at 20 days from the beginning of the immersion experiment (Table 2). At day 30, increased antiprotease activity and lectins were found in larval homogenates treated with A233 and GHRP6 compared with control group (Table 2).

\section{Determination of SOD induction in tilapia larval homogenates}

SOD enzyme activity was measured in larval groups at 20 and 30 days after the beginning of the treatment. There were statistically significant differences between negative controls and the secretagogue-treated groups at 20 days. At 30 days, there were statistically significant differences between the A233 and the GHRP6-treated groups (Table 3).

\section{Discussion}

In this study, we demonstrate for the first time the effect of peptidic molecules having internal cycles and composed solely of L-amino acids that are capable of exerting, due to their chemical structure, similar functions to those attributed to GRLN, des-acyl GRLN, and other peptidic GHS. They are a group of peptide compounds and peptides capable of stimulating production and $\mathrm{GH}$ secretion in vitro and in vivo

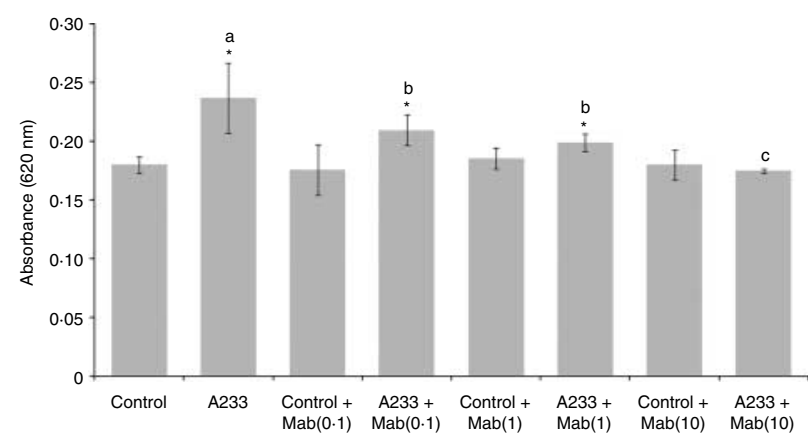

Figure 3 Effect of $\mathrm{GH}$ immunoneutralization on superoxide anion production in HKLs. Cells were incubated with A233 $(10 \mathrm{nM})$ in the presence of anti-tilapia $\mathrm{GH}$ mAb $(0 \cdot 1,1$, and $10 \mu \mathrm{g} / \mathrm{ml})$ for $4 \mathrm{~h}$ at $28{ }^{\circ} \mathrm{C}$ in $5 \% \mathrm{CO}_{2}$. Data are expressed as the absorbance at $620 \mathrm{~nm}$ and bars represent S.D. of the mean (S.E.M., $n=5$ ). Different letters indicate differences between treatments for Newman-Keuls's test. *Significantly different from respective control for the Student's $t$-test. 

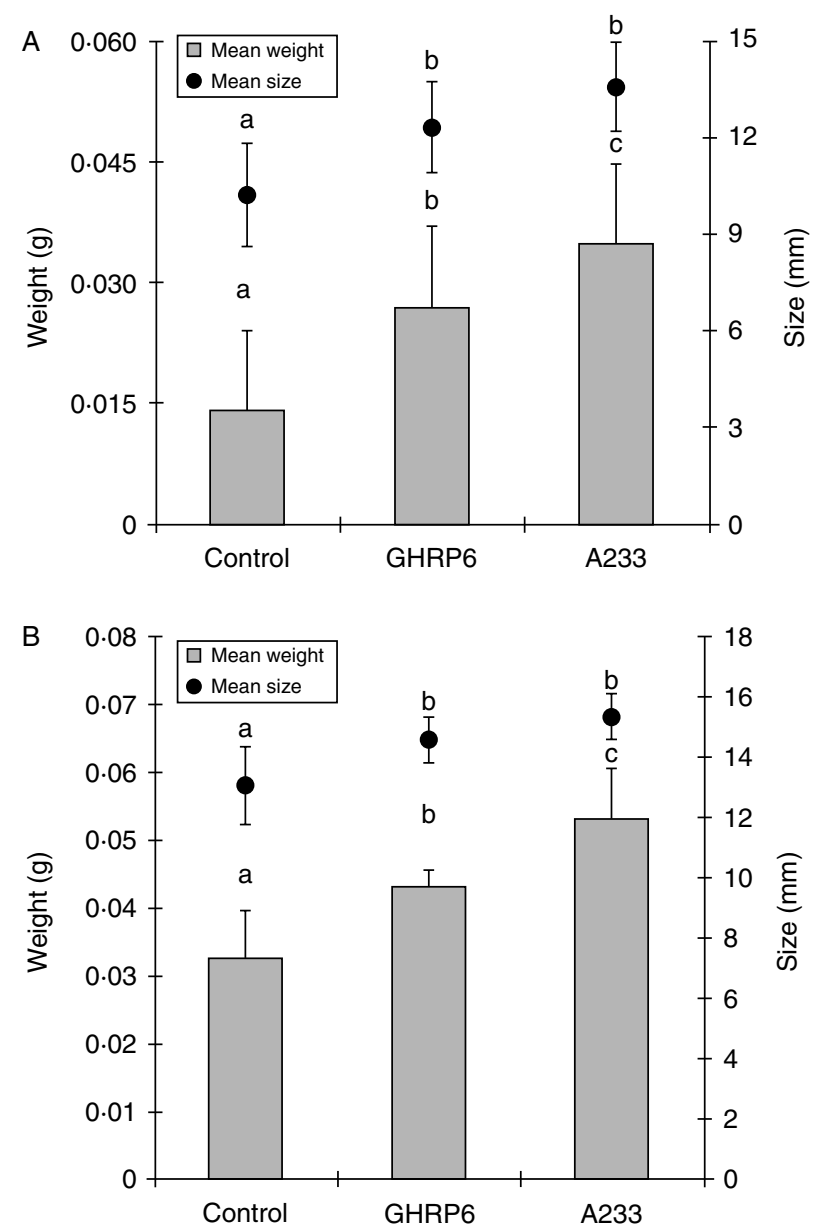

Figure 4 Growth promotion experiment in Carasius auratus and Oreochromis sp. larvae immersed in GHRP6 and A233 peptide at a dose of $0.1 \mathrm{mg} / \mathrm{l}$. (A) Effect on length and weight over 7 days of treatment in goldfish larvae; samples of 50 animals were sized and weighted at 7 days. The control group did not receive any treatment. Kruskal-Wallis test followed by Dunn's multiple comparison posttest was used for length and body weight comparisons among groups. Different letters represent statistical significance. Data are expressed as mean \pm s.D. $(n=50)$. (B) Effect on length and weight over 30 days of treatment in tilapia larvae; samples of 50 animals were sized and weighted at 30 days. The control group did not receive any treatment. Newman-Keuls multiple comparison tests were used for length and body weight comparison among groups. Different letters represent statistical significance. Data are expressed as mean \pm S.D. $(n=50)$.

(Tannenbaum \& Bowers 2001, Moulin et al. 2007), and subsequent investigations have revealed different receptors that can recognize these molecules and the diverse actions they can promote (Veldhuis \& Bowers 2010).

Our results are similar to those obtained in tilapia (Oreochromis mossambicus), where the effect of GRLN on GH secretion in vitro was dependent on the concentration of the endogenous secretagogue used (Kaiya et al. 2003b). Meanwhile, Boaz (2005) observed the stimulating effect of CP-477 335 secretagogue on the secretion of GH by the pituitary gland of
Mozambique tilapia (O. mossambicus) by incubating the body for $8 \mathrm{~h}$ with the synthetic secretagogue. Other researchers have reported the stimulatory effect of the synthetic peptides GHRP6, PACAP, and PACAP-related peptide from Clarias gariepinus on the release of $\mathrm{GH}$ in vitro by the pituitary gland of tilapia (Oreochromis niloticus; Lugo et al. 2008).

There are reports of increased levels of $\mathrm{GH}$ in vivo after treatment with synthetic peptide secretagogues. These results have been observed in tilapia (O. mossambicus) and rainbow trout (O. mykiss) following i.p. injection of the peptide GHRP2 (Shepherd et al. 2000, 2007). However, other researchers did not observe the same effects in the carp (Ctenopharyngodon idellus) treated with GHRP6 or hexarelina (Xiao et al. 2002). The results obtained in the present investigation related to the secretion of $\mathrm{GH}$ in vitro show that A233 is a peptide GHS. Despite the in vitro biological studies that are not enough, it is necessary to carry out in vivo tests to corroborate the stimulating effect of A233 peptide on $\mathrm{GH}$ release.

In teleosts, the morphology of the anterior kidney is similar to the bone marrow of higher vertebrates and is a major hematopoietic organ where phagocytic cells are formed (Whyte 2007). Phagocytic cells produce ROS such as superoxide anion, which help to eliminate many of the pathogens and parasites that infect these animals (Magnadottir 2006, Secombes 2009). The superoxide anion is a ROS produced by the NAPH oxidase complex and are well-known central components in the antimicrobial arsenal of activated phagocytes (Brown et al. 2009). In our case, the stimulation of ROS by A233 could be achieved by the aforementioned NAPH pathway or through the increase in production of mitochondrial-derived ROS. Further experiments should be performed to clarify this mechanism. The phagocytic cells capable of producing these reactive oxygen ions in teleost fish are the monocytes, macrophages, and granulocytes (Zapata \& Amemiya 2000).

The presence of GHSR has been reported in head-kidney of tilapia (O. mossambicus; Fox et al. 2007, Kaiya et al. $2009 a, b, c)$, peripheral blood leukocytes, and leukocytes from the anterior kidney of rainbow trout (O. mykiss), among other tissues (Yada et al. 2006). It has recently been described in two variants of GHSR1a in zebrafish (Danio rerio; Kaiya et al. 2008, Olsson et al. 2008), catfish, and rainbow trout (O. mykiss; Kaiya et al. 2009a,b,c). Moreover, it is reported that the peptide [D-Lys ${ }^{3}$-GHRP6 inhibits the mechanism of signal transduction of synthetic GHSs (Chan et al. 2004, Moulin et al. 2007). Leukocytes isolated from tilapia anterior kidney were treated with the specific antagonist secretagogue receptor $\left[\mathrm{D}-\mathrm{Lys}^{3}\right]$-GHRP6 and subsequently stimulated with peptide A233. The stimulatory effect of peptide A233 on the increased production of superoxide anion was inhibited by pretreatment with the antagonist (Fig. 2). Similar results were observed in the phagocytic leukocytes of rainbow trout (O. mykiss), where the effect of GRLN was eliminated by the presence of GHSR1a antagonist (Yada et al. 2006). The results related to the specific antagonist secretagogue receptor 
Table 2 Protein concentration and innate immunity parameters (anti-tripsin activity and lectins) in control, GHRP6-, and A233-treated groups at 20 and 30 days from the beginning of the immersion experiment. Data represent arithmetic mean \pm s.D. at 20 days $(n=5$ pools of four larvae) and 30 days ( $n=10$ pools of four larvae)

\section{0 days}

Protein

concentration

(mg/g of tissue)

Percentage of
antiprotease activity
(anti-tripsin)

(anti-tripsin)
30 days

\begin{tabular}{|c|c|c|}
\hline $\begin{array}{l}\text { Protein } \\
\text { concentration } \\
\text { (mg/g of tissue) }\end{array}$ & $\begin{array}{l}\text { Percentage of } \\
\text { anti-protease activity } \\
\text { (anti-tripsin) }\end{array}$ & Lectins (titer) \\
\hline $14 \cdot 47 \pm 5 \cdot 92$ & $13 \cdot 19 \pm 2 \cdot 31$ & $6 \cdot 00 \pm 2 \cdot 19$ \\
\hline $9 \cdot 53 \pm 1 \cdot 75$ & $23 \cdot 11 \pm 3 \cdot 98^{\mathrm{a}}$ & $14 \cdot 67 \pm 9 \cdot 35^{a}$ \\
\hline $13 \cdot 97 \pm 5 \cdot 47$ & $28 \cdot 69 \pm 4 \cdot 43^{a}$ & $28 \cdot 00 \pm 9 \cdot 79^{a}$ \\
\hline
\end{tabular}

$28 \cdot 00 \pm 9 \cdot 79^{a}$

\section{Groups}

Control

GHRP6

A233

\begin{abstract}
$10 \cdot 34 \pm 2 \cdot 19$
$10 \cdot 61+2 \cdot 54$

$9 \cdot 51 \pm 0 \cdot 95$
\end{abstract}

$22 \cdot 00 \pm 2 \cdot 84$

$21 \cdot 10+3 \cdot 41$

$19 \cdot 85 \pm 2 \cdot 72$
$3 \cdot 00 \pm 1 \cdot 10$

$4 \cdot 67 \pm 2 \cdot 73$

$5 \cdot 33 \pm 2 \cdot 07$

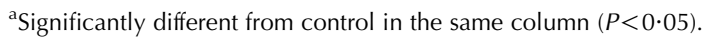

suggest that the A233 peptide action on tilapia leukocytes (Oreochromis sp.) is GHSR1a secretagogue receptor mediated.

The expression of GH and GH receptor has been found in tissues and cells of rat, cattle, and human immune systems, in addition to the distribution of GH mRNA in tissues of the fish immune system (Yada 2007, Hattori 2009). This suggests that $\mathrm{GH}$ acts in an autocrine/paracrine manner on the immune system (Yada et al. 2006, Yada 2007). Other studies show that the effects of GHSs on immune cells may be mediated by the action of GH produced by these cells (Poppi et al. 2002, Yada et al. 2006, Yada 2007, Hattori 2009).

In this study a mixture of monoclonal anti-tiGH peptide with the A233 was administered. The effect of the peptide A233 fell after being administered with the mixture of antibodies in a dose-dependent manner, being observed in the cells treated with $10 \mu \mathrm{g} / \mathrm{ml} \mathrm{mix}$, a response similar to that found in the negative control. Yada et al. (2006) obtained similar results by administering GRLN and a polyclonal anti$\mathrm{GH}$ of salmon to the white blood cells of rainbow trout (O. mykiss). Moreover, these authors reported the increase in the expression levels of GH and SOD in leukocytes stimulated with the endogenous secretagogue. There are several studies that demonstrate the effect of $\mathrm{GH}$ on phagocytic cells. In fish, the increase has been observed in the ingestion of particles by phagocytic leukocytes after in vitro administration of $\mathrm{GH}$, suggesting activation of phagocytosis in these cells (Sakai et al. 1996, Calduch-Giner et al. 1997). Other researchers reported that incubation of peripheral blood leukocytes of rainbow trout (O. mykiss) with isolated GH salmon pituitary significantly stimulated the proliferation of cells (Yada et al. 2004).

The stimulatory effect of A233 on superoxide production was abolished by immunoneutralization with an anti-tiGH $\mathrm{mAb}$ mixture, suggesting the importance of GH secreted by leukocytes, as described by Yada et al. (2006), indicating that the effect of these peptides is mediated through local production of GH.

In vivo studies on the biological function of GHS in fish are scarce and focus mainly on the action of GRLN (Kaiya et al. 2003b, Unniappan \& Peter 2004, Riley et al. 2005, Matsuda et al. 2006, Fox et al. 2007, Jönsson et al. 2007, Picha et al. 2009).
The value of GHSs as useful growth enhancement molecules is clear. These synthetic molecules are effective in stimulating production and release of endogenous hormone as a physiological response, with no side effects on the pituitary or toxicity potential; besides their low molecular weight, it makes a better entrance to the organism.

In our laboratory, we have successfully employed the immersion bath technique to study the effects of nutritional supplements and growth factors on growth control and the immune system in fish (Acosta et al. 2008). The immersion bath method used for our studies requires little manipulation and causes minimum stress to fish during treatment. There is evidence suggesting that the gill pillar cells are a possible entry site for some molecules when fish are treated by immersion bath (Palyha et al. 2000).

This study evaluated the biological function of synthetic peptide A233 on somatic growth of tilapia (Oreochromis sp.) and goldfish larvae (C. auratus). Tilapia larvae showed a significant increase in growth at 20 and 30 days of treatment with peptide A233 $(0 \cdot 1 \mathrm{mg} / \mathrm{l})$. All animals received the same commercial diet, so the increase in weight and height is due to the administration of peptide A233. The positive control group represented by the fish treated with the peptide GHRP6 significantly increased their growth only at 30 days.

Table 3 Determination of SOD induction in tilapia larval homogenates at 20 and 30 days after the beginning of the treatment $^{\mathrm{a}}$. Data represent arithmetic mean $(n=5$ pools $) \pm$ s.D.

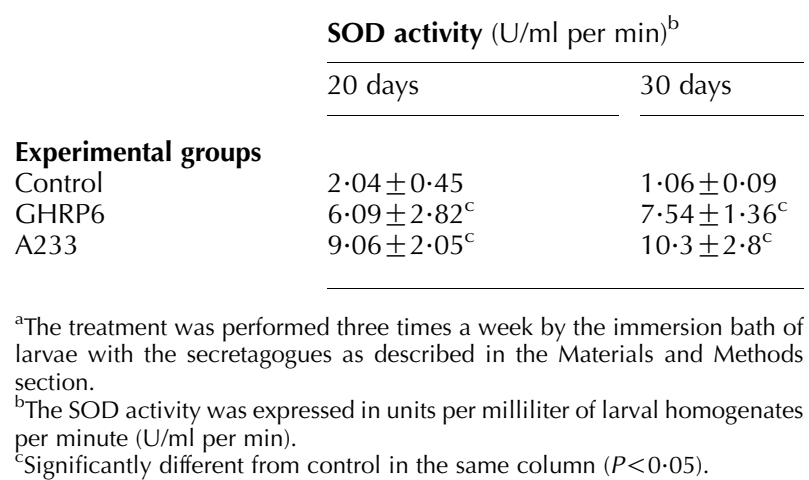

Journal of Endocrinology (2012) 214, 409-419 
In the second fish species used, as early as 1 week after the application of the secretagogue peptide to goldfish larvae, statistically significant increases in body weight and length were obtained in the treated fish larvae compared with the control group. The time difference to show growth enhancement in the species chosen for this work probably reflects species-specific growth characteristics and the important fact that there have been four GHSR1a identified in goldfish derived from four distinct genes. In this species, two uniquely functional GHSRa receptors exist, with differential expression in tissues and distinct ligand selectivity, the GHSR1a acts on energy metabolism (Kaiya et al. 2010).

These results are similar to those found in mice where there was an increase in body weight after dosing by s.c. injection of the synthetic peptide GHRP2 (Tschöp et al. 2002). In adult rats, GHRP6 also increased body weight (Svensson et al. 2000) as well as other GHSR agonists, like SM-130686 administered orally (Nagamine et al. 2001) and BIM-28131 administered by s.c. injection (Strassburg et al. 2008). It has been recently reported that GHSR 1a agonist, a pentapeptide with D-amino acids, promotes weight gain in rats, by i.p. administration during 7 days (Dong et al. 2009). Moreover, the administration, by the same method, of GH tilapia (O. hornorum) secreted into the culture supernatant of yeast Pichia pastori (Acosta et al. 2008) to larvae of tilapia (Oreochromis sp.), significantly increased growth of these animals. Administration of tilapia recombinant neuropeptide $\mathrm{Y}$ (Oreochromis sp.) to larvae of African catfish (C. gariepinus) also produced an increase in animal weight (Carpio et al. 2007). In addition, treatment with PACAP and PACAP-related peptide from C. gariepinus larvae of African catfish (C. gariepinus), tilapia (O. niloticus), and common carp (Cyprinus carpio) increased body weight and length in three fish species (Carpio et al. 2008, Lugo et al. 2008).

Innate immunity is the first line of defense against pathogens that infect fish (Magnadottir 2006, Whyte 2007, AlvarezPellitero 2008). In fish embryos and larvae, innate immunity is very important because they lack acquired immunity (Magnadottir et al. 2005). Moreover, several studies report the use of nutritional supplements, hormones, and peptides as nonspecific immunostimulant immunity in cultured fish larvae as a strategy to improve survival of these organisms at this stage (Peddie et al. 2002, Bricknell \& Dalmo 2005, Martínez et al. 2006, Acosta et al. 2008, Carpio et al. 2008).

In this study, we evaluated some parameters of the innate immune response in larvae treated with the peptide A233. Among the parameters analyzed were the title of lectins and antiprotease activity. Additionally, we assessed the enzymatic activity of SOD as an indicator of antioxidant defense.

Lectins have the function of defense against viruses and bacteria are part of the defense of the fish integument and systemic humoral defenses of innate immunity (Ellis 2001). Carbohydrate-binding proteins are present in pathogens, leading to opsonization, phagocytosis, and activation of the complement system (Magnadottir 2006). Many bacteria produce toxins with proteolytic activity that digest proteins in the host tissue as a result of these protease inhibitors that have a role in defense against pathogens that infect fish (Zuo \& Woo 1997, Woo 2001).

In this study, as the results found in the title of lectins, we identified only a significant increase of antiprotease activity within 30 days of treatment using the peptides. These results suggest that the immunological state enhancing effect of the peptide A233 on some parameters of the immune system of tilapia larvae depends on the number of treatments with the peptide. Moreover, these results are consistent with previous reports showing that immersion baths of nutritional supplement Acuabio 1 increase antiprotease activity and lectin titer in fish larvae (Oreochromis sp.; Martínez et al. 2006). Additionally, the results are similar to those found in larvae of tilapia (Oreochromis sp.) treated with GH tilapia, lacking the 46 last amino acids of the C-terminal, through dips, where the only significant difference was found in antiprotease activity and lectins titer within 30 days of treatment (Acosta et al. 2011).

The action of GRLN and GHS on the cells of the immune system is in correspondence with the widespread distribution of GHS receptors in these tissues (Hattori 2009). In humans, the expression of GHSR has been reported in the spleen, lymph nodes, and lymphocytes (Gnanapavan et al. 2002). The presence of GHSR has also been found in mouse spleen cells and spleen, gill, kidney, and leukocytes in teleost fish (Xia et al. 2004, Yada et al. 2006, Kaiya et al. 2009a,b,c).

The treated larvae exhibit a better growth rate as well as an enhancement of the some innate immune response parameters, improving the larvae quality. It could potentially give them a higher resistance to pathogens and better efficient adaptive response due to the cross talk between innate and acquired immune response. Next, experiments should be conducted to verify how adaptive response is affected in fish with an enhanced innate immune response due to A233 administration. The different parameters of the innate immune response are highly variable, and the application of immunostimulant allows priming of the innate immune response in the larvae population.

Hormones have been reported to modulate antioxidant enzyme activities in mammals (Hauck \& Bartke 2000). In this study, we determined the activity of the antioxidant enzyme SOD in homogenates of larvae treated with peptide A233. In the test performed two times was an increase in the activity of the enzyme in the larvae treated with the peptides. There are reports of fish showing modulation of antioxidant activity due to variations in energy metabolism (Wilhelm Filho et al. 1993, Martínez-Alvarez et al. 2005). Administration or overexpression of $\mathrm{GH}$ produced a significant increase in metabolic rate and oxygen consumption in Atlantic salmon (Salmo salar; Seddiki et al. 1995, 1996, Stevens et al. 1998, Cook et al. 2000, Herbert et al. 2001) and tilapia (Oreochromis sp.; McKenzie et al. 2000). In addition, administration by immersion baths of neuropeptide $\mathrm{Y}$ recombinant African catfish larvae (C. gariepinus) increased the concentration of reduced glutathione and SOD activity, without producing any effect on the activity of catalase (Carpio et al. 2007). Also, in larvae 
of tilapia treated with recombinant tilapia, $\mathrm{GH}$ was increased in the activity of SOD and catalase (Acosta et al. 2011).

The observed increase in antioxidant defenses may neutralize deleterious byproducts of metabolism and counteract the oxidative stress associated with growth. Similar results were obtained by Brown-Borg \& Rakoczy (2003), who observed body weight increase and alteration of multiple components of the antioxidative defense system after $\mathrm{GH}$ administration to dwarf mice.

The results obtained in this research associated with the parameters of the innate immune response and antioxidant defense of the larvae of tilapia indicate, for the first time, the role of the A233 peptide as a stimulator of the immune system of tilapia (Oreochromis sp.).

It would be interesting to determine the temporal and tissue-specific characteristics for activation of tilapia receptors by the new A233 secretagogue peptide. The decapeptide A233 designed by molecular modeling is able to function as a GHS in teleosts. This biological activity was corroborated by the capability of A233 to accelerate the growth rate in fish larvae and to enhance some parameters of the innate immune response and antioxidant defenses through a GH-mediated mechanism.

One of the biggest problems facing aquaculture is the high rates of mortality during the larval stage of fish because of various factors that include diet, physical and chemical factors, and diseases caused by pathogens (Helvik et al. 2009). Therefore, stimulation of growth directed to reduce the time of harvest and high mortality in the larval stages of fish and the use of immunostimulants to prepare them to cope with intensive farming are the key objectives of modern biotechnology. The delivery of A233 by immersion baths to fish larvae stimulates growth, and due to the action of $\mathrm{GH}$, there is also stimulation on various parameters of innate immunity, as evidence of the relationship between the immune and endocrine systems in fish.

\section{Declaration of interest}

The authors declare that there is no conflict of interest that could be perceived as prejudicing the impartiality of the research reported.

\section{Funding}

This research did not receive any specific grant from any funding agency in the public, commercial or not-for-profit sector.

\section{References}

Acosta J, Carpio Y, Besada V, Farnos O, Morales R, Sánchez A, Curbelo Y, Ayala J \& Estrada MP 2008 Recombinant truncated tilapia growth hormone enhances growth and innate immunity in tilapia fry (Oreochromis sp.). General and Comparative Endocrinology 157 49-57. (doi:10.1016/j.ygcen.2008.03.009)
Acosta J, Carpio Y, Morales R, Aguila JC, Acanda Y, Herrera F \& Estrada MP 2010 New insights into the biological activity and secretion properties of a polypeptide derived from tilapia somatotropin. Comparative Biochemistry and Physiology. Part B, Biochemistry \& Molecular Biology 156 264-272. (doi:10.1016/j.cbpb.2010.04.001)

Acosta J, Ruiz O, Carpio Y, Morales R, Aguila JC, Valdés J, Martínez E \& Estrada MP 2011 Thermal treatment enhances the stability and biological activity of a truncated tilapia somatotropin contained in Pichia pastoris culture supernatant. Journal of Biotechnology 151 175-179. (doi:10.1016/j. jbiotec.2010.11.017)

Alvarez-Pellitero P 2008 Fish immunity and parasite infections: from innate immunity to immunoprophylactic prospects. Veterinary Immunology and Immunopathology 126 171-198. (doi:10.1016/j.vetimm.2008.07.013)

Boaz S 2005 Effects of the growth hormone secretagogue, CP-477335, on the GH/IGF-I axis in tilapia, Oreochromis mossambicus. Journal of Young Investigators 12.

Bricknell I \& Dalmo RA 2005 The use of immunostimulants in fish larval aquaculture. Fish \& Shellfish Immunology 19 457-472. (doi:10.1016/j.fsi. 2005.03.008)

Brown-Borg HM \& Rakoczy SG 2003 Growth hormone administration to long-living dwarf mice alters multiple components of the antioxidative defense system. Mechanisms of Ageing and Development 124 1013-1024. (doi:10.1016/j.mad.2003.07.001)

Brown KL, Christenson K, Karlsson A, Dahlgren C \& Bylund J 2009 Divergent effects on phagocytosis by macrophage-derived oxygen radicals. Journal of Innate Immunity 1 592-598. (doi:10.1159/000235583)

Calduch-Giner JA, Sitja-Bobadilla A, Alvarez-Pellitero P \& Pérez-Sánchez J 1997 Growth hormone as an in vitro phagocyte-activating factor in the gilthead sea bream (Sparus aurata). Cell Tissue Research 287 535-540. (doi:10.1007/s004410050777)

Carpio Y, Leon K, Acosta J, Morales R \& Estrada MP 2007 Recombinant tilapia neuropeptide $\mathrm{Y}$ promotes growth and antioxidant defenses in African catfish (Clarias gariepinus) fry. Aquaculture 272 649-655. (doi:10.1016/j. aquaculture.2007.08.024)

Carpio Y, Lugo JM, Leon K, Morales R \& Estrada MP 2008 Novel function of recombinant pituitary adenylate cyclase-activating polypeptide as stimulator of innate immunity in African catfish (Clarias gariepinus) fry. Fish \& Shellfish Immunology 25 439-445. (doi:10.1016/j.fsi.2008.06.004)

Chan CB, Leung PK, Wise H \& Cheng CH 2004 Signal transduction mechanism of the seabream growth hormone secretagogue receptor. FEBS Letters 577 147-153. (doi:10.1016/j.febslet.2004.08.088)

Chang JP \& Wong AOL 2009 Fish neuroendocrinology. Chapter 4 growth hormone regulation in fish: a multifactorial model with hypothalamic, peripheral and local autocrine/paracrine signals. Fish Physiology 28 151-195. (doi:10.1016/S1546-5098(09)28004-6)

Cook JT, McNiven MA \& Sutterlin AM 2000 Metabolic rate of pre-smolt growth-enhanced transgenic Atlantic salmon (Salmo salar). Aquaculture $\mathbf{1 8 8}$ 33-45. (doi:10.1016/S0044-8486(00)00332-X)

Devlin R, Sakhrania D, Tymchuka W, Rise M \& Goha B 2009 Domestication and growth hormone transgenesis cause similar changes in gene expression in coho salmon (Oncorhynchus kisutch). PNAS 106 3047-3052. (doi:10.1073/pnas.0809798106)

Dixit VD, Schaffer EM, Pyle RS, Collins GD, Sakthivel SK, Palaniappan R, Lillard JW \& Taub DD 2004 Ghrelin inhibits leptin- and activationinduced proinflammatory cytokine expression by human monocytes and $\mathrm{T}$ cells. Journal of Clinical Investigation 114 57-66.

Dong JZ, Zhang J, Taylor JE, Halem H, Datta R, Culler M \& Eynon J 2009 GHS-1a agonists that effectively stimulate food intake and body weight gain. Peptides for Youth: the Proceedings of the 20th American Peptide Symposium, Advances in Experimental Medicine and Biology 611 487-488. (doi:10.1007/ 978-0-387-73657-0_210)

Ecobichon DJ 1984 Glutathione depletion and resynthesis in laboratory animals. Drug and Chemical Toxicology 7 345-355. (doi:10.3109/ 01480548408998263)

Ellis AE 2001 Innate host defense mechanisms of fish against viruses and bacteria. Developmental and Comparative Immunology 25 827-839. (doi:10.1016/S0145-305X(01)00038-6) 
Fox BK, Riley LG, Dorough C, Kaiya H, Hirano T \& Grau EG 2007 Effects of homologous ghrelins on the growth hormone/insulin-like growth factor-I axis in the tilapia, Oreochromis mossambicus. Zoological Science $\mathbf{2 4}$ 391-400. (doi:10.2108/zsj.24.391)

Gnanapavan S, Kola B, Bustin SA, Morris DG, McGee P, Fairclough P, Bhattacharya S, Carpenter R, Grossman AB \& Korbonits M 2002 The tissue distribution of the mRNA of ghrelin and subtypes of its receptor, GHS-R, in humans. Journal of Clinical Endocrinology and Metabolism 87 2988-2991. (doi:10.1210/jc.87.6.2988)

Hattori N 2009 Expression, regulation and biological actions of growth hormone (GH) and ghrelin in the immune system. Growth Hormone \& IGF Research 19 187-197. (doi:10.1016/j.ghir.2008.12.001)

Hattori N, Saito T, Yagyu T, Jiang BH, Kitagawa K \& Inagaki C 2001 GH, $\mathrm{GH}$ receptor, $\mathrm{GH}$ secretagogue receptor, and ghrelin expression in human $\mathrm{T}$ cells, B cells, and neutrophils. Journal of Clinical Endocrinology and Metabolism 86 4284. (doi:10.1210/jc.86.9.4284)

Hauck SJ \& Bartke A 2000 Effects of growth hormone on hypothalamic catalase and $\mathrm{Cu} / \mathrm{Zn}$ superoxide dismutase1. Free Radical Biology \& Medicine 28 970-978. (doi:10.1016/S0891-5849(00)00186-6)

Helvik JV, Hamre K, Hordvik I, van der Meeren T, Ressem H, Schartl M, Tveiten H \& Øie G 2009 The fish larva: a transitional life form, the foundation for aquaculture and fisheries. In The Research Council of Norway, pp 5-35. Norway.

Herbert NA, Armstrong JD \& Bjornsson BT 2001 Evidence that growth hormone-induced elevation in routine metabolism of juvenile Atlantic salmon is a result of increased spontaneous activity. Journal of Fish Biology $\mathbf{5 9}$ 754-757. (doi:10.1111/j.1095-8649.2001.tb02379.x)

Howard AD, Feighner SD, Cully DF, Arena JP, Liberator PA \& Rosenblum CI 1996 A receptor in pituitary and hypothalamus that functions in growth hormone release. Science 273 974-977. (doi:10.1126/science.273. 5277.974)

Jönsson E, Forsman A, Einarsdottir IE, Kaiya H, Ruohonen K \& Björnsson BT 2007 Plasma ghrelin levels in rainbow trout in response to fasting, feeding and food composition, and effects of ghrelin on voluntary food intake. Comparative Biochemistry and Physiology. Part A, Molecular \& Integrative Physiology 147 1116-1124. (doi:10.1016/j.cbpa.2007.03.024)

Jung WK, Park PJ \& Kim SK 2003 Purification and characterization of a new lectin from the hard roe of skipjack tuna, Katsuwonus pelamis. International Journal of Biochemistry \& Cell Biology 35 255-265. (doi:10.1016/S13572725(02)00176-0)

Kaiya H, Kojima M, Hosoda H, Riley LG, Hirano T, Grau EG \& Kangawa K 2003a Amidated fish ghrelin: purification, cDNA cloning in the Japanese eel and its biological activity. Journal of Endocrinology 176 415-423. (doi:10.1677/joe.0.1760415)

Kaiya H, Kojima M, Hosoda H, Riley LG, Hirano T \& Grau EG 2003b Identification of tilapia ghrelin and its effects on growth hormone and prolactin release in the tilapia, Oreochromis mossambicus. Comparative Biochemistry and Physiology. Part B, Biochemistry \& Molecular Biology 135 421-429. (doi:10.1016/S1096-4959(03)00109-X)

Kaiya H, Miyazato M, Kangawa K, Peter RE \& Unniappan S 2008 Ghrelin: a multifunctional hormone in non-mammalian vertebrates. Comparative Biochemistry and Physiology. Part A, Molecular \& Integrative Physiology 149 109-128. (doi:10.1016/j.cbpa.2007.12.004)

Kaiya H, Kodama S, Ishiguro K, Matsuda K, Uchiyama M, Miyazato M, Uchiyama M, Miyazato M \& Kangawa K 2009a Ghrelin-like peptide with fatty acid modification and $\mathrm{O}$-glycosylation in the red stingray, Dasyatis akajei. BMC Biochemistry 10 30. (doi:10.1186/1471-209110-30)

Kaiya H, Mori T, Miyazato M \& Kangawa K 2009b Ghrelin receptor (GHS-R)-like receptor and its genomic organisation in rainbow trout, Oncorhynchus mykiss. Comparative Biochemistry and Physiology. Part A, Molecular \& Integrative Physiology 153 438-450. (doi:10.1016/j.cbpa.2009. 04.612)

Kaiya H, Riley LG, Janzen W, Hirano T, Grau EG \& Miyazato M 2009c Identification and genomic sequence of a ghrelin receptor (GHS-R)-like receptor in the Mozambique tilapia, Oreochromis mossambicus. Zoological Science 26 330-337. (doi:10.2108/zsj.26.330)
Kaiya H, Miura T, Matsuda K, Miyazato M \& Kangawa K 2010 Two functional growth hormone secretagogue receptor (ghrelin receptor) type $1 \mathrm{a}$ and $2 \mathrm{~A}$ in goldfish Carassius auratus. Molecular and Cellular Endocrinology 327 25-39. (doi:10.1016/j.mce.2010.06.004)

Kojima M, Hosoda H, Date Y, Nakazato M, Matsuo H \& Kangawa K 1999 Ghrelin is a growth-hormone-releasing acylated peptide from stomach. Nature 402 656-660. (doi:10.1038/45230)

Lugo JM, Rodriguez A, Helguera Y, Morales R, González O, Acosta J, Besada V, Sánchez A \& Estrada MP 2008 Recombinant novel pituitary adenylate cyclase activating polypeptide (PACAP) from African catfish (Clarias gariepinus) authenticates its biological function as a growth promoting factor in low vertebrates. Journal of Endocrinology 197 583-597. (doi:10.1677/JOE-07-0555)

Magnadottir B 2006 Innate immunity of fish (overview). Fish \& Shellfish Immunology 20 137-151. (doi:10.1016/j.fsi.2004.09.006)

Magnadottir B, Jonsdottir H, Helgason S, Bjornsson B, Jorgensen TO \& Pilstrom L 1999 Humoral immune parameters in Atlantic cod (Gadus morhua L.). II. The effects of size and gender under different environmental conditions. Comparative Biochemistry and Physiology. Part B, Biochemistry \& Molecular Biology 122 181-188. (doi:10.1016/S0305-0491(98)10157-8)

Magnadottir B, Lange S, Gudmundsdottir S, Bogwald J \& Dalmo RA 2005 Ontogeny of humoral immune parameters in fish. Fish \& Shellfish Immunology 19 429-439. (doi:10.1016/j.fsi.2005.03.010)

Martínez R, Carpio Y, Gómez Y, Raíces M, Morales A, Herrera F, González O, Morales R \& Estrada MP 2006 Acuabio 1 estimula el metabolismo anaerobio y el sistema inmune innato de las larvas de goldfish y tilapia. Biotecnología Aplicada 23 287-293.

Martínez-Alvarez RM, Morales AE \& Sanz A 2005 Antioxidant defenses in fish: biotic and abiotic factors. Reviews in Fish Biology and Fisheries 15 75-88. (doi:10.1007/s11160-005-7846-4)

Matsuda K, Miura T, Kaiya H, Maruyama K, Shimakura S, Uchiyama M, Kangawa K \& Shioda S 2006 Regulation of food intake by acyl and des-acyl ghrelins in the goldfish. Peptides 27 2321-2325. (doi:10.1016/ j.peptides.2006.03.028)

McKenzie DJ, Martínez R, Morales A, Acosta J, Taylor EW, Steffensen JF \& Estrada MP 2000 Metabolic rate, exercise performance and hypoxia tolerance of growth hormone transgenic tilapia (Oreochromis sp.). Comparative Biochemistry and Physiology. Part B, Biochemistry \& Molecular Biology 126 S66. (doi:10.1016/S0305-0491(00)80130-3)

Momany FA, Bowers CY, Reynolds GA, Chang D, Hong A \& Newlander K 1981 Design, synthesis and biological activity of peptides which release growth hormone, in vitro. Endocrinology 108 31-39. (doi:10.1210/endo108-1-31)

Moulin A, Ryan J, Martinez J \& Fehrentz JA 2007 Recent developments in ghrelin receptor ligands. ChemMedChem 2 1242-1259. (doi:10.1002/cmdc. 200700015)

Muccioli G, Baragli A, Granata R, Papotti M \& y Ghigo E 2007 Heterogeneity of Ghrelin/Growth Hormone Secretagogue Receptors. Toward the Understanding of the Molecular Identity of Novel Ghrelin/GHS Receptors. Neuroendocrinology 86 147-164.

Nagamine J, Nagata R, Seki H, Nomura-Akimaru N, Ueki Y, Kumagai K, Taiji M \& Noguchi H 2001 Pharmacological profile of a new orally active growth hormone secretagogue, SM-130686. Journal of Endocrinology 171 481-489. (doi:10.1677/joe.0.1710481)

Olsson C, Holbrook JD, Bompadre G, Jönsson E, Hoyle CH, Sanger GJ, Holmgren S \& Andrews PL 2008 Identification of genes for the ghrelin and motilin receptors and a novel related gene in fish, and stimulation of intestinal motility in zebrafish (Danio rerio) by ghrelin and motilin. General and Comparative Endocrinology 155 217-226. (doi:10.1016/j.ygcen. 2007.05.016)

Palyha OC, Feighner SD, Tan CP, McKee KK, Hreniuk DL \& Gao YD 2000 Ligand activation domain of human orphan growth hormone (GH) secretagogue receptor (GHS-R) conserved from Pufferfish to humans. Molecular Endocrinology 14 160-169. (doi:10.1210/me.14.1.160)

Peddie S, Zou J \& Secombes CJ 2002 Immunomodulation in the rainbow trout (Oncorhynchus mykiss) following intraperitoneal administration of Ergosan. Veterinary Immunology and Immunopathology 86 101-113. (doi:10.1016/S0165-2427(02)00019-3) 
Picha ME, Strom CN, Riley LG, Walker AA, Won ET, Jhnstone WM \& Borski RJ 2009 Plasma ghrelin and growth hormone regulation in response to metabolic state in hybrid striped bass: effects of feeding, ghrelin and insulin-like growth factor-I on in vivo and in vitro GH secretion. General and Comparative Endocrinology 161 365-372. (doi:10.1016/j.ygcen. 2009.01.026)

Poppi L, Dixit VD, Baratta M, Giustina A, Tamanini C \& Parvizi N 2002 Growth hormone secretagogue (GHS) analogue, hexarelin stimulates GH from peripheral lymphocytes. Experimental and Clinical Endocrinology \& Diabetes 110 343-347. (doi:10.1055/s-2002-34991)

Riley LG, Fox BK, Kaiya H, Hirano T \& Grau EG 2005 Long-term treatment of ghrelin stimulates feeding fat deposition, and alters the GH/IGF-I axis in the tilapia (Oreochromis mossambicus). General and Comparative Endocrinology 142 234-240. (doi:10.1016/j.ygcen.2005.01.009)

Rise ML, Douglas S, Sakharani D, Williams J, Ewart KV, Rise M, Davidson WS, Koop BF \& Devlin RH 2006 Multiple microarray platforms utilized for hepatic gene expression profiling of $\mathrm{GH}$ transgenic coho salmon with and without ration restriction. Journal of Molecular Endocrinology 37 259-282. (doi:10.1677/jme.1.02031)

Rodriguez R, De la Nuez A, Estrada MP, Martinez R, Chinea G, Reyes O, Fernandez R, Garcia D, Berlanga A \& Musacchio A 2007 Compounds analogous to growth hormone peptide secretagogues and preparations containing them. (Patent publication No.: WO 2007/098716 A1).

Sakai M, Kobayashi M \& Kawauchi H 1996 Mitogenic effect of growth hormone and prolactin on chum salmon Oncorhynchus keta leukocytes in vitro. Veterinary Immunology and Immunopathology 53 185-189. (doi:10.1016/0165-2427(95)05507-X)

Secombes CJ 1997 The NonspecificImmune System: Cellular Defenses. Fish Physiology 15 63-103. (doi:10.1016/S1546-5098(08)60272-1)

Seddiki H, Maxime V, Boeuf G \& Peyraud C 1995 Effects of growth hormone on plasma ionic regulation, respiration and extracellular acid-base status in trout (Oncorhynchus mykiss) transferred to seawater. Fish Physiology and Biochemistry 14 279-288. (doi:10.1007/BF00004066)

Seddiki H, Boeuf G, Maxime V \& Peyraud C 1996 Effects of growth hormone treatment on oxygen consumption and sea water adaptability in Atlantic salmon parr and pre-smolts. Aquaculture 148 49-62. (doi:10.1016/ S0044-8486(96)01407-X)

Shepherd BS, Eckert SM, Parhar IS, Vijayan MM, Wakabayashi I \& Hirano T 2000 The hexapeptide KP-102 (D-ala-D-beta-Nal-ala-trp-D-phe-lys$\mathrm{NH}(2)$ ) stimulates growth hormone release in a cichlid fish (Oreochromis mossambicus). Journal of Endocrinology 167 7-10. (doi:10.1677/joe.0. 167R007)

Shepherd BS, Johnson JK, Silverstein JT, Parhar IS, Vijayan MM, McGuire A \& Weber GM 2007 Endocrine and orexigenic actions of growth hormone secretagogues in rainbow trout (Oncorhynchus mykiss). Comparative Biochemistry and Physiology. Part A, Molecular \& Integrative Physiology 146 390-399. (doi:10.1016/j.cbpa.2006.11.004)

Sherwood NM, Krueckl SL \& McRory JE 2000 The origin and function of the pituitary adenylate cyclase-activating polypeptide (PACAP)/glucagon superfamily. Endocrine Reviews 21 619. (doi:10.1210/er.21.6.619)

Small BC, Quiniou SMA \& Kaiya H 2009 Sequence, genomic organization and expression of two channel catfish, Ictalurus punctatus, ghrelin receptors. Comparative Biochemistry and Physiology. Part A, Molecular \& Integrative Physiology 154 451-464. (doi:10.1016/j.cbpa.2009.07.027)

Strassburg S, Anker SD, Castaneda TD, Burget L, Perez-Tilve D, Pfluger PT, Nogueiras R, Halem H, Dong J, Culler M et al. 2008 Long-term effects of ghrelin and ghrelin receptor agonists on energy balance in rats. American Journal of Physiology. Endocrinology and Metabolism 295 E78-E84. (doi:10.1152/ajpendo.00040.2008)

Stevens ED, Sutterlin A \& Cook T 1998 Respiratory metabolism and swimming performance in growth hormone transgenic Atlantic salmon. Canadian Journal of Fisheries and Aquaculture Sciences 55 2028-2035. (doi:10.1139/f98-078)
Svensson SJ, Lall S, Dickson L, Bengtssonl B-Å, Romer J, Ahnfelt-Ronne I, Ohlsson C \& Jansson J-O 2000 The GH secretagogues ipamorelin and GH-releasing peptide-6 increase bone mineral content in adult female rats. Journal of Endocrinology 165 569-577. (doi:10.1677/joe.0.1650569)

Tannenbaum GS \& Bowers CY 2001 Interactions of growth hormone secretagogues and growth hormone-releasing hormone/somatostatin. Endocrine 14 21-27. (doi:10.1385/ENDO:14:1:021)

Tschöp M, Statnick MA, Suter TM \& Heiman ML 2002 GH-releasing peptide-2 increases fat mass in mice lacking NPY: indication for a crucial mediating role of hypothalamic agouti-related protein. Endocrinology 143 558-568. (doi:10.1210/en.143.2.558)

Unniappan S \& Peter RE 2004 In vitro and in vivo effects of ghrelin on luteinizing hormone and growth hormone release in goldfish. American Journal of Physiology. Regulatory, Integrative and Comparative Physiology 286 R1093-R1101. (doi:10.1152/ajpregu.00669.2003)

Veldhuis JD \& Bowers CY 2010 Integrating GHS into the ghrelin system. International Journal of Peptides 2010 1-40. (doi:10.1155/2010/879503)

Whyte SK 2007 The innate immune response of finfish - a review of current knowledge. Fish \& Shellfish Immunology 23 1127-1151. (doi:10.1016/j.fsi. 2007.06.005)

Wilhelm Filho D, Giulivi C \& Boveris A 1993 Antioxidant defenses in marine fish. I. Teleosts. Comparative Biochemistry and Physiology 106 409-413.

Woo PTK 2001 Cryptobiosis and its control in north American fishes. International Journal for Parasitology 31 566-574. (doi:10.1016/S00207519(01)00169-2)

Xia Q, Pang W, Pan H, Zheng Y, Kang JS \& Zhu SG 2004 Effects of ghrelin on the proliferation and secretion of splenic $\mathrm{T}$ lymphocytes in mice. Regulatory Peptides 122 173-178. (doi:10.1016/j.regpep.2004. 06.016)

Xiao D, Chu MM, Lee EK, Lin HR \& Wong AO 2002 Regulation of growth hormone release in common carp pituitary cells by pituitary adenylate cyclase-activating polypeptide: signal transduction involves cAMP- and calcium-dependent mechanisms. Neuroendocrinology 76 325-338. (doi:10.1159/000066627)

Yada T 2007 Growth hormone and fish immune system. General and Comparative Endocrinology 152 353-358. (doi:10.1016/j.ygcen.2007. 01.045)

Yada T, Muto K, Azuma T \& Ikuta K 2004 Effects of prolactin and growth hormone on plasma levels of lysozyme and ceruloplasmin in rainbow trout. Comparative Biochemistry and Physiology. Toxicology \& Pharmacology 139 57-63. (doi:10.1016/j.cca.2004.09.003)

Yada T, Kaiya H, Mutoh K, Azuma T, Hyodo S \& Kangawa K 2006 Ghrelin stimulates phagocytosis and superoxide production in fish leukocytes. Journal of Endocrinology 189 57-65. (doi:10.1677/joe.1. 06187)

Zapata G \& Amemiya T 2000 Phylogeny of lower vertebrates and their immunological structures. In Origin and Evolution of the Vertebrate Immune System, ch 8. pp 67-110. Heidelberg: Springer-Verlag.

Zuo X \& Woo PTK 1997 Natural anti-proteases in rainbow trout, Oncorhynchus mykiss and brook charr, Salvelinus fontinalis and the in vitro neutralization of fish $[\alpha] 2$-macroglobulin by the metalloprotease from the pathogenic haemoflagellate, Cryptobia salmositica. Parasitology 114 375-382. (doi:10.1017/S0031182096008578)

Received in final form 10 May 2012

Accepted 15 June 2012

Made available online as an Accepted Preprint 15 June 2012 